\title{
Removal of heavy metals using different polymer matrixes as support for bacterial immobilisation
}

\author{
Carlos Pires $^{\mathrm{a}, \mathrm{b}}$, Ana P.G.C. Marques ${ }^{\mathrm{a}}$, António Guerreiro ${ }^{\mathrm{b}}$, Naresh Magan ${ }^{\mathrm{b}}$, Paula M.L. Castro ${ }^{\mathrm{a}, *}$ \\ ${ }^{a}$ CBQF/Escola Superior de Biotecnologia, Universidade Católica Portuguesa, Rua Dr. António Bernardino de Almeida, 4200-072 Porto, Portugal \\ b Cranfield Health, Vincent Building, Cranfield University, Cranfield, Bedford MK43 OAL, UK
}

Keywords:

Heavy metals

Bacterial immobilisation

Synthetic polymer

Acetate

Pectate

Binary mixtures

\begin{abstract}
A B S T R A C T
Great attention is focused on the microbial treatment of metal contaminated environments. Three bacterial strains, 1C2, 1ZP4 and EC30, belonging to genera Cupriavidus, Sphingobacterium and Alcaligenes, respectively, showing high tolerance to $\mathrm{Zn}$ and $\mathrm{Cd}$, up to concentrations of $1000 \mathrm{ppm}$, were isolated from a contaminated area in Northern Portugal. Their contribution to $\mathrm{Zn}$ and $\mathrm{Cd}$ removal from aqueous streams using immobilised alginate, pectate and a synthetic cross-linked polymer was assessed. In most cases, matrices with immobilised bacteria showed better metal removal than the non-inoculated material alone. For the immobilisation with all the polymers, 1C2 was the strain that increased the removal of $\mathrm{Zn}$ the most, whereas EC30 was the most promising for Cd removal, especially when combined with the synthetic polymer with up to a ca. 11-fold increase in metal removal when compared to the polymer alone. Removal of individual metals from binary mixtures showed that there was differential immobilisation. There was greater removal of $\mathrm{Cd}$ than $\mathrm{Zn}$ (removals up to $40 \%$ higher than those showed for $\mathrm{Zn}$ ). The results show that metal contaminated environments constitute a reservoir of microorganisms resistant/tolerant to heavy metals that have the capacity to be exploited in bioremediation strategies.

Capsule immobilisation of bacteria in the naturally occurring alginate and pectate and in a synthetic cross-linked polymer increased the $\mathrm{Zn}$ and $\mathrm{Cd}$ removal abilities from single and binary contaminated waters; the applications with the synthetic polymer were the most promising for $\mathrm{Cd}$ and $\mathrm{Zn}$ removal in single and binary mixtures.
\end{abstract}

\section{Introduction}

Heavy metal pollution is one of the most important environmental problems today, especially in relation to water contamination. Several industries, mining and smelting, as well as production of fuel, energy, fertilizers, metallurgy, electroplating, electrolysis, leatherworking and photography [1] produce waste and wastewaters that are discharged in water courses threatening the ecosystems and ultimately human health. Traditional methods of metal removal generally consist of physical and/or chemical approaches which are often expensive, with high energy and chemical requirements, producing high amounts of residues [2]. They are often not effective especially for low to moderate metal concentrations [3]. In this context, the search for more effective methods is necessary to reduce heavy metal contamination in waste water to environmentally acceptable levels. Biologically

\footnotetext{
* Corresponding author. Tel.: +351 225580059; fax: +351225090351

E-mail addresses: cmpires@mail.esb.ucp.pt (C. Pires), amarques@mail.esb.ucp.pt (A.P.G.C. Marques), a.guerreiro@cranfield.ac.uk (A. Guerreiro),

n.magan@cranfield.ac.uk (N. Magan), plcastro@esb.ucp.pt (P.M.L. Castro).
}

based, eco-friendly and economically more attractive technologies are required.

Biosorption is a method that involves the use of biological materials that form complexes with metal ions using their functional groups [4]. In the process, a chemical link between functional groups on the biosorbent and the metal ions present in solution or an ion-exchange reaction due to the high ion-exchange capacity of the biosorbent may occur [5]. Bacteria have a high surface areato-volume ratio and can thus provide a large contact surface, which allows the interaction with metals in its surroundings [6], and have been successfully used as biosorbents [7-9]. However, studies demonstrate that sometimes living systems are inconsistent, especially when using freely suspended biomass. In fact, although freely suspended biomass can promote higher contact with the contaminants during the removal process, it is usually unpractical as a clean-up method [10]. Biopolymers are non-toxic and when used to immobilise biomass may help improve biosorption capacity and facilitate biomass separation from metal bearing solutions. This can then be a non-destructive process if necessary and allow the regeneration of biosorbents for multiple uses, as well as increasing biomass concentration $[11,12]$. The ion-exchange process that occurs in such polymers when exposed to water contaminated 
with metals [13] is complemented with the biosorption capacity of the immobilised microorganisms. Other alternative is the use of synthetic polymers as matrices that can control or promote bioadhesion. Potential applications for materials that are bio-adherent or bio-compatible are widespread [14]. Usually the synthesis of functional polymeric materials involves the use of a functional monomer to impart the desired characteristics to the final material and a cross-linker which will give the necessary rigidity to the polymer network. The main advantages of using these materials is the possibility to fine-tune the final properties by varying polymer composition, robustness and stability under a wide range of chemical and physical conditions.

Common matrices used to support organisms (either of natural or synthetic origin) include hydrogels [15], activated alumina and charcoal [16], kaolin [2], polyacrylonitrile [17], alginate and pectate.

The objectives of this study were to compare the use of alginate, pectate and a synthetic porous cross-linked polymer as immobilisation matrices for metal resistant bacteria species, comparing the contribution of different bacteria in the removal of the metals $\mathrm{Cd}$ and $\mathrm{Zn}$, supplied alone and as mixed metal solutions.

\section{Materials and methods}

\subsection{Isolation and selection of heavy metal resistant bacterial strains}

Selected bacterial species were isolated from a metal contaminated site - Estarreja, Northern Portugal. Despite the high presence of metals - average levels of $835 \mathrm{mg} \mathrm{Pb} \mathrm{kg}^{-1}$, $66 \mathrm{mg} \mathrm{Hg} \mathrm{kg}{ }^{-1}, \quad 26 \mathrm{mg} \mathrm{Cr} \mathrm{kg}^{-1}, \quad 37 \mathrm{mg} \mathrm{Ni} \mathrm{kg}^{-1}, \quad 16,800 \mathrm{mg} \mathrm{Fe} \mathrm{kg}{ }^{-1}$ and $3620 \mathrm{mg} \mathrm{Zn} \mathrm{kg}^{-1}$ (total $\mathrm{Zn}$ ) - the area is prolific in vegetation [18]. Several bacterial strains were isolated from the non-rhizosphere and rhizosphere soils. Soil samples were collected and serially diluted in saline solution $(0.85 \%(\mathrm{w} / \mathrm{v}) \mathrm{NaCl})$ and inoculated on trypticase soy agar (TSA; Oxoid) at $30^{\circ} \mathrm{C}$. Visually different colonies selected on the basis of colony morphology and colour were further purified [19]. For this study, 3 strains isolated at $\mathrm{pH}$ 7 designated as 1ZP4, EC30 and 1C2, were selected based on their metal tolerance in in vitro screening assays. Cell morphology was tested as described by Alexander and Strete [20]. Gram staining tests were performed as described by Murray et al. [21] and Smibert and Krieg [22]. The $\mathrm{pH}$ range for growth was determined in buffered trypticase soy broth (TSB) adjusted at pH 3-10 (at $1 \mathrm{pH}$ unit intervals). The turbidity of the cultures grown in an orbital shaker at $25^{\circ} \mathrm{C}$ was measured at $610 \mathrm{~nm}$. All buffer solutions used to adjust the $\mathrm{pH}$ of TSB were prepared from $1 \mathrm{M}$ stock solutions [23]. Citrate buffer was used for $\mathrm{pH} 3-6$, phosphate buffer for $\mathrm{pH}$ 7, Tris- $\mathrm{HCl}$ buffer for $\mathrm{pH} \mathrm{8,} \mathrm{and} \mathrm{a} \mathrm{carbonate-bicarbonate} \mathrm{buffer} \mathrm{for} \mathrm{pH} 9$ and 10 . Growth temperature ranges were determined at 15, 20, 25, 30, $37^{\circ} \mathrm{C}$ on TSB and on TSA at 4,10 , and $50^{\circ} \mathrm{C}$. Extraction of genomic DNA, PCR amplification of the 16S rRNA gene and sequencing of the purified PCR products were carried out as described by Rainey et al. [24]. Cloning of the amplicons into pGEM T-Easy vector (Promega) and cycle-sequencing were performed at Macrogen Inc. (Seoul, Republic of Korea), using 16S universal bacterial primers (f27, f518, r800, r1492) [25]. The quality of the 16S rRNA gene sequences was checked manually by the use of the BioEdit program (version 7.0.5.3) [26], and the sequences were aligned against representative reference sequences of the most closely related members obtained from the National Center for Biotechnology Information database [27].

\subsection{Effect of metals on bacterial growth in suspension cultures}

Three hundred millilitre Erlenmeyer flasks containing $100 \mathrm{ml}$ TSB supplemented with heavy metals at concentrations of 50 ,
$100 \mathrm{mg} \mathrm{L}^{-1}\left(\mathrm{Cd}^{2+}\right), 100,250 \mathrm{mg} \mathrm{L}^{-1}\left(\mathrm{Zn}^{2+}\right)$ and metal mixtures of $200 \mathrm{mg} \mathrm{L}^{-1}\left[100 \mathrm{mgL}^{-1}\left(\mathrm{Cd}^{2+}\right)+100 \mathrm{mg} \mathrm{L}^{-1}\left(\mathrm{Zn}^{2+}\right)\right]$ were inoculated with the bacterial strains in order to achieve a starting optic density (OD) of 0.1 at $610 \mathrm{~nm}$. The metals were applied as salts $\mathrm{ZnCl}_{2}$ and $\mathrm{CdCl}_{2}$. All the cultures, including controls (in triplicate), were incubated at $30^{\circ} \mathrm{C}$ for $24 \mathrm{~h}$ at $150 \mathrm{rpm}$. Bacterial growth was monitored at time intervals by measuring the optical density at $610 \mathrm{~nm}$ and the specific growth rate of each strain was determined. The strains with the highest growth rate were EC30, 1ZP4 and 1C2 and were selected for further characterisation and for the uptake tests.

\subsection{Synthetic cross-linked polymer synthesis}

Polymers were prepared by mixing in a $100 \mathrm{ml}$ glass bottle $40 \mathrm{~g}$ ethylene glycol dimethacrylate, $0.37 \mathrm{~g} \mathrm{~N}, \mathrm{~N}$-diethylamino ethyl methacrylate, $2 \mathrm{~g}$ polyethylene glycol 35,000, $40.37 \mathrm{~g}$

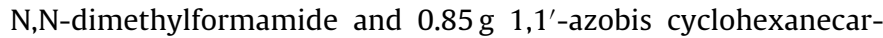
bonitrile. The mixture was bubbled with nitrogen for $5 \mathrm{~min}$ and sealed with Teflon coated caps. Polymerisation took $20 \mathrm{~min}$ and was initiated using an UVAPRINT 100 CVI UV source with a $0.163 \mathrm{~W} / \mathrm{cm}^{2}$ intensity [28]. The resulting polymer monolith was crushed manually in a mortar with a pestle and the particles in the range 200-500 $\mu \mathrm{m}$ collected using sieves from Endecotts, UK. Polymers were then washed with methanol overnight in a sohxlet apparatus in order to remove any unreacted monomers and the polyethylene glycol and after dried at $60^{\circ} \mathrm{C}$ during $6 \mathrm{~h}$. Polymers were produced with weak alkaline monomers in order to promote bacterial adhesion. The composition of the polymer was adapted from Barral et al. [29].

\subsection{Bacterial immobilisation}

The bacterial strains (EC30, 1ZP4 and 1C2) were grown in $300 \mathrm{ml}$ Erlenmeyer flasks containing $100 \mathrm{ml}$ TSB until the cell biomass reached an OD of $1.0(610 \mathrm{~nm})$. Cells were harvested by centrifugation at $6000 \mathrm{rpm}$ for $15 \mathrm{~min}$ and the bacterial pellet weighed and washed using sterile ultra-pure water. The harvested biomass was re-suspended in $25 \mathrm{ml}$ sterile Universal bottles containing $5 \mathrm{ml}$ of saline solution $(0.85 \%, \mathrm{w} / \mathrm{v})$.

For Ca-alginate and Ca-pectate, the bacterial inoculum was immobilised under aseptic conditions, using the method described by Escamilla et al. [30] and Montes and Magana [31] with some modifications. The inoculum $[\mathrm{OD}=1(610 \mathrm{~nm})$, which represented a fresh weight of $74 \mathrm{mg}$ for 1C2, $108 \mathrm{mg}$ for $1 \mathrm{ZP} 4$ and $128 \mathrm{mg}$ for EC30, in a volume of $100 \mathrm{ml}$ ] was adjusted in a volumetric cylinder to $1: 1$ inoculum/polymer ratio by using alginic acid (Sigma) or polygalacturonic (Sigma) $4 \%(\mathrm{w} / \mathrm{v})$ concentrated. The solution was homogenized and forced though a needle template (gauge for $\pm 3 \mathrm{~mm}$ beads) with a peristaltic pump (Watson-Marlow Bredel, Wilmington, Mass.) flowing at $10 \mathrm{ml} \mathrm{m}^{-1}$, and the droplets were collected in a sterile gel inducer solution of $3.5 \%(\mathrm{w} / \mathrm{v}) \mathrm{CaCl}_{2}$. After soaking for $1 \mathrm{~h}$, the liquid was decanted and the spherical beads were washed with sterile ultra pure water. In aseptic conditions the beads were then packed into sterile $6 \mathrm{ml}$ fritted SPE tubes (Supelco) with a filter. An adaptor cap (Phenomenex) was fitted to each of the tubes. For the synthetic polymer, $1 \mathrm{~g}$ was packed in sterile $6 \mathrm{ml}$ fritted SPE tubes (Supelco) containing a filter under aseptic conditions. Bacterial biomass was then added to the tube (fresh weight of $150 \mathrm{mg}$ ). An adaptor cap (Phenomenex) was fitted to each of the tubes. Tubes were then left to settle for $1 \mathrm{~h}$ at room temperature. An additional alternative method was used with the synthetic polymer. The bacterial strains were grown in $300 \mathrm{ml}$ Erlenmeyer flasks containing $100 \mathrm{ml} \mathrm{TSB}$ and $3 \mathrm{~g}$ of the synthetic polymer until cells grew to $1.0 \mathrm{OD}(610 \mathrm{~nm})$. Cells and polymer were then harvested by centrifugation at $6000 \mathrm{rpm}$ for $15 \mathrm{~min}$ and the bacterial 
Table 1

Characteristics of strains 1ZP4, EC30 and 1C2.

\begin{tabular}{llll}
\hline Characteristic & 1ZP4 & EC30 & $1 \mathrm{C} 2$ \\
\hline $\begin{array}{l}\text { Colony pigmentation } \\
\text { Cell morphology }\end{array}$ & $\begin{array}{l}\text { White } \\
\text { Rod }\end{array}$ & $\begin{array}{l}\text { White } \\
\text { Rod }\end{array}$ & $\begin{array}{l}\text { Pearly white } \\
\text { Rod }\end{array}$ \\
$\begin{array}{l}\text { Gram } \\
\text { Growth temperature }\left({ }^{\circ} \mathrm{C}\right)\end{array}$ & - & - & - \\
$\begin{array}{l}\text { Range } \\
\text { Optimum }\end{array}$ & $10-40$ & $10-40$ & $10-40$ \\
pH for growth & $25-30$ & 30 & 25 \\
Range & $5-9$ & $5-9$ & $5-9$ \\
Optimum & 7 & $7-8$ & $6-7$ \\
\hline
\end{tabular}

and polymer pellet was weighted. Under aseptic conditions $1.5 \mathrm{~g}$ of the pellet containing the bacterial biomass and the synthetic polymer was packed in sterile $6 \mathrm{ml}$ fritted SPE tubes (Supelco) with filter. An adaptor cap (Phenomenex) was fitted to each of the tubes. Tubes were then left to settle for $1 \mathrm{~h}$ at room temperature.

In every case, polymers were washed prior use and recirculation was made until OD of washing solution was bellow $0.1(610 \mathrm{~nm})$.

\subsection{Heavy metal uptake tests}

For metal uptake batch experiments, $5 \mathrm{ml}$ of a solution $(\mathrm{pH}$ ranging from 6.50 to 7.01 ) containing $100 \mathrm{mg} \mathrm{L}^{-1}$ of $\mathrm{Cd}^{2+}, \mathrm{Zn}^{2+}$ or a mixed metal solution containing $100 \mathrm{mg} \mathrm{L}^{-1}$ of each of the metals was added to the polymer packed tubes - metals for the solutions preparation were applied as their salts $\mathrm{ZnCl}_{2}$ and $\mathrm{CdCl}_{2}$. Three sequential cycles of $5 \mathrm{ml}$ were tested for each treatment, with an average contact time of $2 \mathrm{~min}$. Outlet solutions were collected filtered using a Puradisc 25 Syringe Filter (Whatman) and the amount of residual metal present in solution was measured by atomic absorption spectrophotometry in a Hitachi Z-8100 Atomic absorption spectrophotometer, with Zeeman correction.

\subsection{Statistical analysis}

Each treatment was comprised of 3 replicates. Statistical analysis was performed using the SPSS program (SPSS Inc., Chicago, IL Version 15.0). The data were analysed through variance analysis (ANOVA). To detect the statistical significance of differences $(P<0.05)$ between means, the Tukey test was performed.

\section{Results}

\subsection{Bacterial strains}

The tested phenotypic characteristics of strains 1ZP4, EC30 and $1 \mathrm{C} 2$ are given in Table 1 . The $\mathrm{pH}$ and temperature ranges for growth of the strains were similar. Full length (about 1250-1450 bp) $16 \mathrm{~S}$ rRNA of strains 1ZP4, EC30 and 1C2 were sequenced and the closest affiliation according to sequencing were for strain 1ZP4 Sphingobacterium sp. MG2 (AY556417), for EC30 Alcaligenes sp. S-SL-5 (FJ529025) and for 1C2 Cupriavidus sp. 2CSa-12 (GU167923).

\subsection{Growth of $1 Z P 4, E C 30$ and $1 C 2$ in the presence of heavy metals}

Growth curves for strains 1ZP4, EC30 and 1C2 in the presence of $\mathrm{Zn}^{2+}$ are shown in Fig. 1. At the concentrations tested, $\mathrm{Zn}^{2+}$ had only a small effect on their growth. Growth of strains 1ZP4, EC30 and $1 \mathrm{C} 2$ was significantly reduced when TSB medium contained $\mathrm{Cd}^{2+}$ (Fig. 1). 1C2 was the strain most affected by the presence of $\mathrm{Cd}$. Remarkably, none of the tested strains showed a significant lag phase. Final biomass concentration was lower when $100 \mathrm{mg} \mathrm{L}^{-1}$ of $\mathrm{Cd}^{2+}$ was applied (Fig. 1).
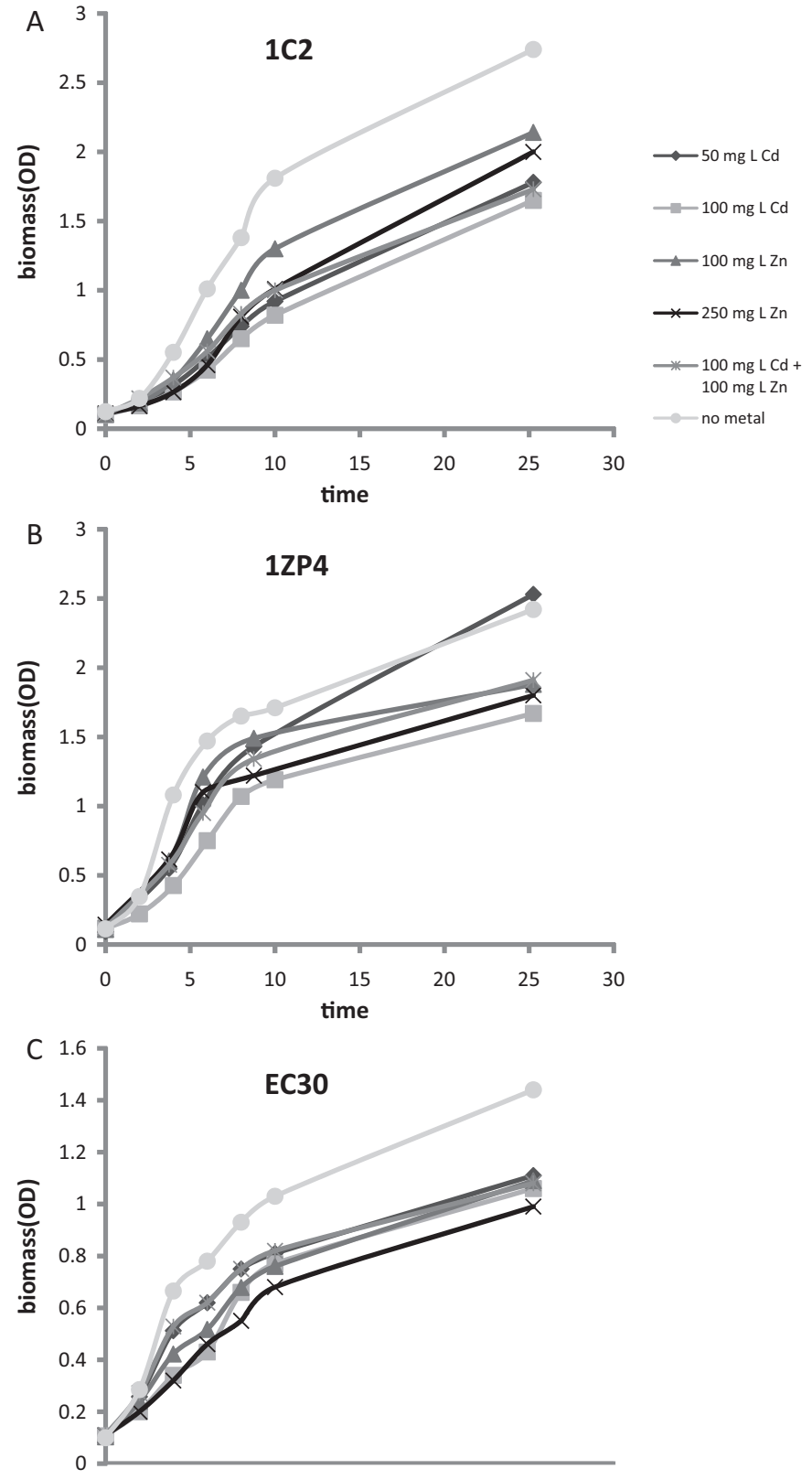

Fig. 1. Growth curves of strains $1 \mathrm{C} 2$ (A), 1ZP4 (B) and EC 30 (C) under 50 and $100 \mathrm{mg} \mathrm{Cd} / \mathrm{L}, 100$ and $250 \mathrm{mg} \mathrm{Zn} / \mathrm{L}, 100 \mathrm{mg} \mathrm{Cd}+100 \mathrm{mg} \mathrm{Zn} / \mathrm{L}$ and no metal.

When a metal mixture was used growth of strain $1 \mathrm{C} 2$ was visibly reduced (Fig. 1), which can possibly be attributed to the presence of $\mathrm{Cd}$. On the other hand, the metal mixture had less effect on the growth of strains EC30 and 1ZP4. In fact, for strain EC30, part of the exponential growth phase was similar to the control growth (Fig. 1).

\subsection{Removal of single metals in solution by different matrices and immobilised bacterial strains}

\subsubsection{Removal of $Z n$}

The matrix type and bacterial immobilisation had a significant $(P<0.05)$ effect on $\mathrm{Zn}$ removal. In general, the treatments that included bacteria showed significantly $(P<0.05)$ better $\mathrm{Zn}$ removal than the matrices on their own, as shown by the significantly lower concentrations of $\mathrm{Zn}$ in the outlet of the cartridges. ANOVA two way test results were, in summary, after the 
first removal cycle, $F_{\mathrm{Zn}(\text { matrix })}=434(P<0.001), F_{\mathrm{Zn} \text { (bacteria) }}=1124$ $(P<0.001)$ and $F_{Z n}($ matrix $\times$ bacteria $)=154 \quad(P<0.001)$; for the second cycle $F_{Z n(m a t r i x)}=446(P<0.001), F_{Z n \text { (bacteria) }}=725(P<0.001)$ and $F_{\mathrm{Zn}(\text { matrix } \times \text { bacteria })}=253(P<0.001)$; and for the third cycle $F_{\mathrm{Zn}(\text { matrix })}=69.4 \quad(P<0.001), \quad F_{\mathrm{Zn} \text { (bacteria) }}=175 \quad(P<0.001) \quad$ and $F_{\mathrm{Zn}(\text { matrix } \times \text { bacteria })}=58.5(P<0.001)$.

For each specific matrix (alginate, pectate, synthetic polymer and incubated synthetic polymer), the effect of the bacterial application on $\mathrm{Zn}$ removal was determined using one way ANOVA. In the alginate matrix, generally inoculation with strain EC30 immobilised in alginate gave the best immobilisation of this metal (Table 2$)$. The removal varied significantly $(P<0.05)$ within cycles of metal application, showing that a clear relationship between the repeated use and the removal efficiency cannot generally be drawn for alginate. For pectate-based treatments, generally strain 1ZP4 was the best strain. However, in by the third cycle there was no difference between treatments $(P<0.05)$. Removals of $\mathrm{Zn}$ by the synthetic polymer matrix based treatments are also shown in Table 2. In general, strain 1C2 was more active when combined with the synthetic polymer. Over time (1-3 cycles) this combination became less efficient at removing this metal. When the bacterial cells were incubated with the synthetic polymer prior to packing, again strain $1 \mathrm{C} 2$ was the best treatment and $t$ significantly $(P<0.05)$ enhanced $\mathrm{Zn}$ removal in this matrix (Table 2 ). Overall, strain $1 \mathrm{C} 2$ immobilised on the synthetic polymer $(P Y+1 C 2)$ was the best treatment and was significantly $(P<0.05)$ better (up to $76 \%$ more metal removed), than the other treatments especially in cycles 1 and 2 . Effective removal was also observed for the polymer with EC30 $(P Y+E C 30)$ and for both these combinations when bacteria were incubated with the polymer (PYInc+1C2 and PYInc + EC30).

Adsorption efficiencies to bacterial biomass per unit weight of cells were estimated and are shown in Table 4 for each bacterial treatment. For $\mathrm{Zn}$ removal in single solutions, higher adsorption levels were obtained for the PYInc + EC30 mixture, with an efficiency of $2.2 \mathrm{mg} \mathrm{Zn}^{-1}$ bacterial cells.

\subsubsection{Removal of $\mathrm{Cd}$}

The matrix type and bacterial strain immobilisation had a significant $(P<0.05)$ effect on $\mathrm{Zn}$ removal (two-way ANOVA). In all cycles, the treatments that included bacteria showed significantly $(P<0.05)$ better $C d$ removal than when the matrices were used alone. Test results were for the 1 st cycle $F_{\mathrm{Cd}(\text { matrix })}=756(P<0.001)$, $F_{\mathrm{Cd}(\text { bacteria })}=1524(P<0.001)$ and $F_{\mathrm{Cd}(\text { matrix } \times \text { bacteria })}=135(P<0.001)$; for the second cycle $F_{\mathrm{Cd}(\text { matrix })}=185(P<0.001), F_{\mathrm{Cd}(\text { bacteria })}=630$ $(P<0.001)$ and $F_{\mathrm{Cd}(\text { matrix } \times \text { bacteria })}=272(P<0.001)$; and for the third cycle $F_{\mathrm{Cd}(\text { matrix })}=45.2(P<0.001), F_{\mathrm{Cd}(\text { bacteria })}=645(P<0.001)$ and $F_{\text {Cd }(\text { matrix } \times \text { bacteria })}=209(P<0.001)$.

As for $\mathrm{Zn}$, Cd removal was compared for each specific matrix treatment alone and with immobilised bacterial strains. Strain EC30 immobilised in alginate was shown to significantly immobilise this metal (Table 3 ). The behaviour of these combinations of alginate-bacteria was also analysed throughout the cycles and it generally varied with time, with significant $(P<0.05)$ differences in the removal efficiencies between the three cycles. Strains 1ZP4 and $1 \mathrm{C} 2$ immobilised in pectate significantly $(P<0.05)$ increased $\mathrm{Cd}$ removal. The behaviour of these pectate-bacteria combinations varied throughout the cycles. Immobilisation with strain EC30 in the synthetic polymer gave a 11-fold increase in the removal of $\mathrm{Cd}$ when compared with the polymer alone; additionally, all the treatments showed a significant $(P<0.05)$ decrease of removal efficiency of $\mathrm{Cd}$ throughout the cycles, similarly to what happened for Zn (Table 3) When the bacteria were incubated with the synthetic polymer prior to packing, no specific treatment was found to be more effective than any other. However, strains EC30 and 1C2 immobilised directly with the polymer matrix improved removal (Table 3). For all cycles, strain EC30 immobilisation onto the synthetic polymer (PY + EC30) was the best treatment.

Cadmium adsorption efficiencies per unit weight of cells (Table 4) in single solutions were determined and higher adsorption levels were also obtained for the PYInc + EC30 mixture, with an efficiency of $2.8 \mathrm{mg} \mathrm{Cd} \mathrm{g}^{-1}$ bacterial cells.

\subsection{Removal of binary mixtures of metals by matrices and immobilised bacterial strains}

The ability of the bacterial tested strains to take up metals from binary mixtures was then determined. Strain EC30 was best at removing $\mathrm{Cd}$ from the binary mixtures, regardless of immobilising system used (see Table 3 ). All the treatments showed significant $(P<0.05)$ variations in the removal efficiencies of $\mathrm{Cd}$ throughout the cycles, according to one-way ANOVA performed on data. For $\mathrm{Zn}$, strain EC30 immobilised in the alginate matrix improved the differential uptake $(P<0.05)$ (Table 3$)$, while strain 1ZP4 enhanced metal uptake when immobilised in pectate. Strain $1 \mathrm{C} 2$ was best at removing $\mathrm{Zn}$ from the binary mixtures when using the synthetic polymer. Overall, strain $1 \mathrm{C} 2+\mathrm{PY}$ was best at differentially taking up $\mathrm{Zn}$. As previously observed, by the third cycle metal removal was much less than in the earlier cycles.

Zinc and $\mathrm{Cd}$ adsorption efficiencies per unit weight of cells in the binary solution were also determined (Table 4) and the best performance was found for the treatments PYInc $+1 \mathrm{C} 2$ and $\mathrm{PY}+1 \mathrm{C} 2$ for $\mathrm{Zn}$, with an adsorption level of $1.8 \mathrm{mg} \mathrm{Zn} \mathrm{g}^{-1}$ cells, and for $\mathrm{P}+1 \mathrm{C} 2$ and $A+1 C 2$ for $C d$, registering efficiencies of $2.2 \mathrm{mg} \mathrm{Cd} \mathrm{g}^{-1}$ cell.

$\mathrm{Zn}$ removal in single $(\mathrm{Zn})$ and binary $(\mathrm{Zn}+\mathrm{Cd})$ mixtures in each treatment were also compared pair wise using the $t$-test (Table 2). For all matrices and cycles, differences in the ability to remove $\mathrm{Zn}$ were observed between simple and binary contamination scenarios, which seem to indicate that the performance of the treatments is influenced not only by the concentration but also by the metal feed composition. The same procedure was used for $\mathrm{Cd}$ removal in single $(\mathrm{Cd})$ and binary $(\mathrm{Zn}+\mathrm{Cd})$ solutions (Table 3$)$. As in the case of $\mathrm{Zn}$, for all matrixes and cycles, differences in Cd removal were observed between simple and binary contamination scenarios.

$\mathrm{Cd}$ and $\mathrm{Zn}$ removal in the binary mixture were compared using the $t$-test. Results showing levels of the metals in the outlet (in $\mathrm{mM}$ ) are presented in Fig. 2 for alginate, and indicate that levels of $\mathrm{Cd}$ in the outlet were always significantly $(P<0.05)$ lower than those of $\mathrm{Zn}$. For pectate based combinations, the same trend was observed (Fig. 3). With the exception of 1C2 immobilised to the synthetic polymer treatment, that presented no significant $(P<0.05)$ differences in $\mathrm{Cd}$ and $\mathrm{Zn}$ removal in cycle 1 (Fig. 4), levels of $\mathrm{Cd}$ at the outlet were significantly $(P<0.05)$ lower than those of $\mathrm{Zn}$ in the polymer based treatments (Figs. 4 and 5), decrease that showed to be of up to $65 \%$. It seems thus that generally the tested bacteria-matrix combinations had higher affinity for $\mathrm{Cd}$ when a binary mixture was present.

\section{Discussion}

The aim of the work was to assess the effect of bacterial immobilisation in metal removal, and to compare the efficiency of bacteria + polymer combinations in order to understand which combinations were most appropriate for use in the clean-up of $\mathrm{Cd}$ and $\mathrm{Zn}$ contaminated waters.

\subsection{Removal of individual metals by immobilised bacterial matrices}

Metal sequestration by a sorbent may be due to one or a combination of the following processes: ion exchange, physical adsorption, chemisorptions, complexation or microprecipitation 
Table 2

Levels of $\mathrm{Zn}$ in the outlet for each treatment ( $\mathrm{mg} \mathrm{Zn} \mathrm{L}^{-1}$ ).

\begin{tabular}{|c|c|c|c|c|c|c|}
\hline \multirow[t]{2}{*}{ Treatment } & \multicolumn{2}{|l|}{ Round 1} & \multicolumn{2}{|l|}{ Round 2} & \multicolumn{2}{|l|}{ Round 3} \\
\hline & $100 \mathrm{mg} Z \mathrm{Zn} / \mathrm{L}$ & $100 \mathrm{mg} Z \mathrm{Zn}+100 \mathrm{mgCd} / \mathrm{L}$ & 100 mg Zn/L & $100 \mathrm{mgZn}+100 \mathrm{mg} \mathrm{Cd} / \mathrm{L}$ & $100 \mathrm{mg} Z \mathrm{Zn} / \mathrm{L}$ & $100 \mathrm{mg} \mathrm{Zn}+100 \mathrm{mg} \mathrm{Cd} / \mathrm{L}$ \\
\hline $\begin{array}{l}A \\
A+1 C 2 \\
A+1 Z P 4 \\
A+E C 30\end{array}$ & $\begin{array}{l}97.4 \pm 0.1^{\mathrm{gh}, \mathrm{D}} \\
83.4 \pm 0.5^{\mathrm{ef}, \mathrm{C}} \\
52 \pm 3^{\mathrm{c}, \mathrm{A}} \\
64.9 \pm 0.2^{\mathrm{d}, \mathrm{B}} \\
* * * F=513\end{array}$ & $\begin{array}{l}92 \pm 2^{\mathrm{ef}, \mathrm{C} \neq} \\
81 \pm 2^{\mathrm{de}, \mathrm{B}} \\
66 \pm 5^{\mathrm{c}, \mathrm{A} \neq} \\
70 \pm 2^{\mathrm{cd}, \mathrm{A} \neq} \\
*_{* * *} F=44.2\end{array}$ & $\begin{array}{l}84 \pm 2^{\mathrm{ef}, \mathrm{B}} \\
87.8 \pm 0.3^{\mathrm{f}, \mathrm{B}} \\
84 \pm 2^{\mathrm{efv}, \mathrm{B}} \\
69 \pm 2^{\mathrm{d}, \mathrm{A}} \\
*^{* * *} F=67.1\end{array}$ & $\begin{array}{l}84 \pm 6^{\mathrm{fg}, \mathrm{BC}} \\
89.8 \pm 0.8^{\mathrm{g}, \mathrm{C} \neq} \\
75.7 \pm 0.09^{\mathrm{df}, \mathrm{AB} \neq} \\
74 \pm 3^{\mathrm{d}, \mathrm{A}} \\
{ }^{* *} F=14,5\end{array}$ & $\begin{array}{l}82 \pm 1^{\mathrm{ef}, \mathrm{B}} \\
87,1 \pm 0.6^{\mathrm{f}, \mathrm{C}} \\
79 \pm 4^{\mathrm{def}, \mathrm{B}} \\
71.0 \pm 0.8^{\mathrm{cd}, \mathrm{A}} \\
* * * F=35.6\end{array}$ & $\begin{array}{l}76 \pm 0^{\mathrm{abc}, \mathrm{AB}} \\
83 \pm 2^{\mathrm{abc}, \mathrm{C}} \\
79 \pm 2^{\mathrm{abc}, \mathrm{BC}} \\
73.9 \pm 0.8^{\mathrm{abc}, \mathrm{A} \neq} \\
*^{*} F=16.3\end{array}$ \\
\hline $\begin{array}{l}P \\
P+1 C 2 \\
P+1 Z P 4 \\
P+E C 30\end{array}$ & $\begin{array}{l}91 \pm 1^{\mathrm{gh}, \mathrm{C}} \\
79 \pm 2^{\mathrm{e}, \mathrm{B}} \\
41 \pm 2^{\mathrm{b}, \mathrm{A}} \\
80.28 \pm 0.03^{\mathrm{e}, \mathrm{B}} \\
{ }^{* * *} F=588\end{array}$ & $\begin{array}{l}99 \pm 2^{\mathrm{f}, \mathrm{C} \neq} \\
77.8 \pm 0.4^{\mathrm{d}, \mathrm{B}} \\
44 \pm 2^{\mathrm{b}, \mathrm{A}} \\
74 \pm 3^{\mathrm{cd}, \mathrm{B} \neq} \\
* * * * F=386\end{array}$ & $\begin{array}{l}79.4 \pm 0.7^{\mathrm{e}, \mathrm{B}} \\
80 \pm 3^{\mathrm{e}, \mathrm{B}} \\
68 \pm 3^{\mathrm{d}, \mathrm{A}} \\
80 \pm 1^{\mathrm{e}, \mathrm{B}} \\
* * * * 21.0\end{array}$ & $\begin{array}{l}77 \pm 4^{\mathrm{df}, \mathrm{A}} \\
83.5 \pm 0.6^{\mathrm{fg}, \mathrm{B}} \\
74 \pm 2^{\mathrm{cd}, \mathrm{A} \neq} \\
76.8 \pm 0.3^{\mathrm{df}, \mathrm{A} \neq} \\
{ }^{* *} F=10.4\end{array}$ & $\begin{array}{l}74 \pm 2^{\text {cde,A }} \\
79 \pm 6^{\text {def,A }} \\
79.9 \pm 0.8^{\text {defg,A }} \\
77 \pm 2^{\text {de,A }} \\
{ }^{N S} F=2.14\end{array}$ & $\begin{array}{l}65 \pm 0^{\mathrm{a}, \mathrm{A} \neq} \\
82.425 \pm 0.005^{\mathrm{abc}, \mathrm{D}} \\
75.5 \pm 0.6^{\mathrm{abc}, \mathrm{B} \neq} \\
79.7 \pm 0.5^{\mathrm{abc}, \mathrm{C} \neq} \\
*^{* * *} F=734\end{array}$ \\
\hline $\begin{array}{l}P Y \\
P Y+1 C 2 \\
P Y+1 Z P 4 \\
P Y+E C 30\end{array}$ & $\begin{array}{l}102.05 \pm 0.05^{\mathrm{h}, \mathrm{C}} \\
26 \pm 4^{\mathrm{a}, \mathrm{A}} \\
44 \pm 4^{\mathrm{b}, \mathrm{B}} \\
22 \pm 2^{\mathrm{a}, \mathrm{A}} \\
* * * F=477\end{array}$ & $\begin{array}{l}101.4 \pm 0.6^{\mathrm{f}, \mathrm{C}} \\
22 \pm 6^{\mathrm{a}, \mathrm{A}} \\
46 \pm 2^{\mathrm{b}, \mathrm{B}} \\
35 \pm 12^{\mathrm{b}, \mathrm{AB}} \\
*^{* * *} F=82.6\end{array}$ & $\begin{array}{l}105.5 \pm 0.8^{\mathrm{h}, \mathrm{D}} \\
31.9 \pm 0.5^{\mathrm{a}, \mathrm{A}} \\
68 \pm 2^{\mathrm{d}, \mathrm{C}} \\
50 \pm 2^{\mathrm{c}, \mathrm{B}} \\
*_{* * *} F=1118\end{array}$ & $\begin{array}{l}106.2 \pm 0.6^{\mathrm{h}, \mathrm{D} \neq} \\
42,0 \pm 0.1^{\mathrm{a}, \mathrm{A} \neq} \\
73 \pm 2^{\mathrm{cd}, \mathrm{C}} \\
64 \pm 5^{\mathrm{bc}, \mathrm{B}^{*}} \\
{ }^{* * * *} F=305\end{array}$ & $\begin{array}{l}109.0 \pm 0.4^{\mathrm{g}, \mathrm{B}} \\
74 \pm 8^{\mathrm{cde}, \mathrm{A}} \\
99 \pm 1^{\mathrm{g}, \mathrm{B}} \\
65 \pm 4^{\mathrm{c}, \mathrm{A}} \\
*^{* * *} F=64.6\end{array}$ & $\begin{array}{l}108.6 \pm 0.3^{\mathrm{c}, \mathrm{A}} \\
72.3 \pm 0.2^{\mathrm{abc}, \mathrm{A}} \\
101 \pm 1^{\mathrm{abc}, \mathrm{A}} \\
76 \pm 6^{\mathrm{abc}, \mathrm{A}} \\
{ }^{\mathrm{NS}} F=1.41\end{array}$ \\
\hline $\begin{array}{l}\text { PYInc } \\
\text { PYInc + 1C2 } \\
\text { PYInc + 1ZP4 } \\
\text { PYInc + EC30 }\end{array}$ & $\begin{array}{l}96 \pm 4^{\mathrm{gh}, \mathrm{C}} \\
28 \pm 4^{\mathrm{a}, \mathrm{AB}} \\
37 \pm 4^{\mathrm{b}, \mathrm{B}} \\
25 \pm 3^{\mathrm{a}, \mathrm{A}} \\
*^{* * *} F=277\end{array}$ & $\begin{array}{l}101 \pm 1^{\mathrm{f}, \mathrm{C}} \\
18.9 \pm 0.5^{\mathrm{a}, \mathrm{A} \neq} \\
44 \pm 3^{\mathrm{b}, \mathrm{B}} \\
21 \pm 1^{\mathrm{a}, \mathrm{A}} \\
{ }^{* * *} F=1503\end{array}$ & $\begin{array}{l}96 \pm 1^{\mathrm{g}, \mathrm{C}} \\
41 \pm 4^{\mathrm{b}, \mathrm{A}} \\
47.5 \pm 0.4^{\mathrm{c}, \mathrm{B}} \\
38.7 \pm 0.4^{\mathrm{b}, \mathrm{A}} \\
*^{* * *} F=520\end{array}$ & $\begin{array}{l}103.99 \pm 0.06^{\mathrm{h}, \mathrm{C}} \\
48 \pm 7^{\mathrm{a}, \mathrm{A}} \\
44 \pm 4^{\mathrm{a}, \mathrm{A}} \\
60 \pm 2^{\mathrm{b}, \mathrm{B} \neq} \\
*_{* * *} F=140\end{array}$ & $\begin{array}{l}101 \pm^{\mathrm{g}, \mathrm{D}} \\
51 \pm 3^{\mathrm{b}, \mathrm{B}} \\
79 \pm 3^{\mathrm{def}, \mathrm{C}} \\
39 \pm 4^{\mathrm{a}, \mathrm{A}} \\
{ }^{* * *} F=254\end{array}$ & $\begin{array}{l}106 \pm 4^{\mathrm{bc}, \mathrm{C}} \\
67 \pm 2^{\mathrm{ab}, \mathrm{A} \neq} \\
79 \pm 3^{\mathrm{abc}, \mathrm{B}} \\
70 \pm 2^{\mathrm{abc}, \mathrm{A}} \\
* * * F=118\end{array}$ \\
\hline & $\left.{ }^{* * *} F=404\right)$ & $* * *(F=172)$ & $* * *(F=387)$ & $* * *(F=108)$ & $* * *(F=84)$ & $*(F=2.52)$ \\
\hline
\end{tabular}

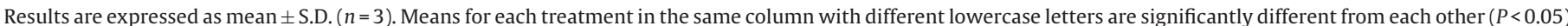

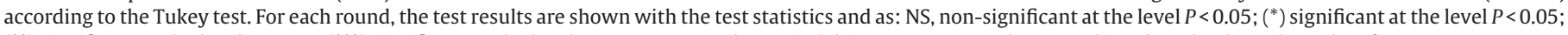

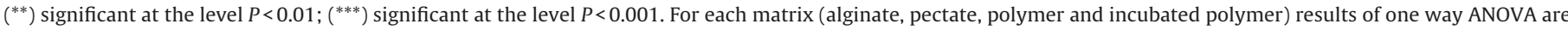

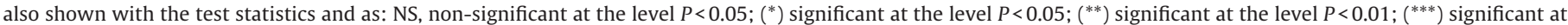

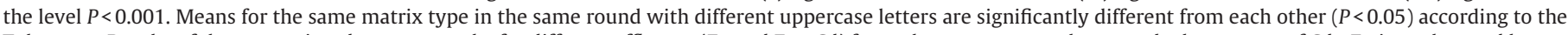

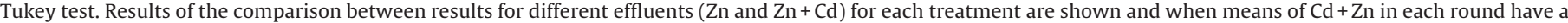
$\neq$ signal they are significantly different from means of outlet $\mathrm{Zn}(P<0.05)$ according to the $t$-test.

Table 3

Levels of $\mathrm{Cd}$ in the outlet for each treatment $(\mathrm{mg} \mathrm{Cd} / \mathrm{L})$.

\begin{tabular}{|c|c|c|c|c|c|c|}
\hline \multirow[t]{2}{*}{ Treatment } & \multicolumn{2}{|l|}{ Round 1} & \multicolumn{2}{|l|}{ Round 2} & \multicolumn{2}{|l|}{ Round 3} \\
\hline & $100 \mathrm{mg} \mathrm{Cd} / \mathrm{L}$ & $100 \mathrm{mg} Z \mathrm{n}+100 \mathrm{mg} \mathrm{Cd} / \mathrm{L}$ & $100 \mathrm{mg} C d / \mathrm{L}$ & $100 \mathrm{mg} Z \mathrm{n}+100 \mathrm{mg} \mathrm{Cd} / \mathrm{L}$ & $100 \mathrm{mg} \mathrm{Cd} / \mathrm{L}$ & $100 \mathrm{mg} Z \mathrm{n}+100 \mathrm{mgCd} / \mathrm{L}$ \\
\hline A & $88 \pm 2^{\mathrm{f}, \mathrm{C}}$ & $85 \pm 2^{\mathrm{h}, \mathrm{A}}$ & $61.5 \pm 0.3^{\mathrm{f}, \mathrm{B}}$ & $61 \pm 2^{\text {def, } A}$ & $63.1 \pm 0.1^{\mathrm{e}, \mathrm{B}}$ & $60 \pm 1^{\mathrm{a}, \mathrm{AB}} \neq$ \\
\hline$A+1 C 2$ & $67.9 \pm 0.2^{e, B}$ & $72 \pm 1^{\mathrm{gB}}$ & $68 \pm 2^{\mathrm{fg}, \mathrm{C}}$ & $65 \pm 2^{\mathrm{ef}, \mathrm{A}}$ & $69 \pm 1^{\mathrm{e}, \mathrm{B}}$ & $68.0 \pm 0.9^{\text {bcde }, c}$ \\
\hline$A+1 Z P 4$ & $63.3 \pm 0.4^{\mathrm{de}, \mathrm{B}}$ & $58.47 \pm 0.05^{\mathrm{d}, \mathrm{A} \neq}$ & $64 \pm 1^{\mathrm{fg}, \mathrm{BC}}$ & $61 \pm 2^{\text {def,A }}$ & $66 \pm 5^{\mathrm{e}, \mathrm{B}}$ & $58 \pm 3^{\mathrm{a}, \mathrm{A}}$ \\
\hline \multirow[t]{2}{*}{$A+E C 30$} & $47 \pm 4^{\mathrm{c}, \mathrm{A}}$ & $60 \pm 1^{\mathrm{de}, \mathrm{A} \neq}$ & $45 \pm 2^{\mathrm{d}, \mathrm{A}}$ & $63 \pm 1^{\text {ef, }, \mathrm{A} \neq}$ & $48 \pm 1^{\mathrm{cd}, \mathrm{A}}$ & $62.7 \pm 0.4^{\mathrm{abc}, \mathrm{B} \neq}$ \\
\hline & $* * * F=147$ & $* * * F=239$ & $* * * F=144$ & ${ }^{\mathrm{NS}} F=3.18$ & ${ }^{* * *} F=35.6$ & ${ }^{* * * *} F=22.4$ \\
\hline $\mathrm{P}$ & $92 \pm 3^{f, C}$ & $86 \pm 1^{\mathrm{h}, \mathrm{B} \neq}$ & $54 \pm 2^{\mathrm{e}, \mathrm{A}}$ & $58 \pm 3^{\mathrm{de}, A}$ & $65.7 \pm 0.3^{\mathrm{e}, \mathrm{A}}$ & $64 \pm 7^{\mathrm{abcd}, \mathrm{AB}}$ \\
\hline$P+1 C 2$ & $63 \pm 1^{\mathrm{de}, \mathrm{AB}}$ & $64.1 \pm 0.4^{\mathrm{ef}, \mathrm{A}}$ & $69.2 \pm 0.7^{\mathrm{g}, \mathrm{B}}$ & $69 \pm 1^{\mathrm{f}, \mathrm{C}}$ & $65 \pm 1^{\mathrm{e}, \mathrm{A}}$ & $69.6 \pm 0.2^{\mathrm{de}, \mathrm{B} \neq}$ \\
\hline $\mathrm{P}+1 \mathrm{ZP} 4$ & $58 \pm 3^{\mathrm{d}, \mathrm{A}}$ & $61.9 \pm 0.8^{\text {def, } A}$ & $64.8 \pm 0.8^{\mathrm{fg}, \mathrm{B}}$ & $64.9 \pm 0.5^{\mathrm{ef}, \mathrm{B}}$ & $65 \pm 2^{\mathrm{e}, \mathrm{A}}$ & $57 \pm 3^{\mathrm{a}, \mathrm{A} \neq}$ \\
\hline \multirow{2}{*}{$P+E C 30$} & $68 \pm 4^{\mathrm{e}, \mathrm{B}}$ & $64 \pm 3^{f, A}$ & $64 \pm 5^{\mathrm{fg}, \mathrm{B}}$ & $59.92 \pm 0.07^{\text {def,A }}$ & $64 \pm 2^{\mathrm{e}, \mathrm{A}}$ & $61 \pm 1^{\mathrm{a}, \mathrm{AB}}$ \\
\hline & ${ }^{* * *} F=87.7$ & $* * * F=76.0$ & ${ }^{* * *} F=18.7$ & $* * * F=34.8$ & ${ }^{N S} F=1.03$ & ${ }^{*} F=6.32$ \\
\hline PY & $91.9 \pm 0.3^{\mathrm{f}, \mathrm{C}}$ & $98.24 \pm 0.03^{\mathrm{i}, \mathrm{C} \neq}$ & $92.46 \pm 0.07^{\mathrm{h}, \mathrm{D}}$ & $96.9 \pm 0.2^{g, C \neq}$ & $95.7 \pm 0.5^{\mathrm{f}, \mathrm{C}}$ & $100 \pm 2^{\mathrm{f}, \mathrm{C} \neq}$ \\
\hline$P Y+1 C 2$ & $21 \pm 1^{\mathrm{b}, \mathrm{B}}$ & $40 \pm 1^{\mathrm{c}, \mathrm{B} \neq}$ & $36 \pm 3^{c, C}$ & $63.8 \pm 0.9^{\mathrm{ef}, \mathrm{B} \neq}$ & $49 \pm 3^{\mathrm{cd}, \mathrm{B}}$ & $69 \pm 2^{\text {cdeB }, \neq}$ \\
\hline$P Y+1 Z P 4$ & $6 \pm 2^{\mathrm{a}, \mathrm{A}}$ & $38.41 \pm 0.05^{\mathrm{c}, \mathrm{B}} \neq$ & $25 \pm 4^{\mathrm{bc}, \mathrm{B}}$ & $33 \pm 4^{\mathrm{a}, \mathrm{A}}$ & $46 \pm 4^{\mathrm{b}, \mathrm{B}}$ & $61.7 \pm 0.7^{\mathrm{ab}, \mathrm{A} \neq}$ \\
\hline \multirow[t]{2}{*}{$P Y+E C 30$} & $5 \pm 1^{\mathrm{a}, \mathrm{A}}$ & $23 \pm 1^{\mathrm{b}, \mathrm{A}} \neq$ & $15.8 \pm 0.7^{\mathrm{a}, \mathrm{A}}$ & $38 \pm 6^{\mathrm{a}, \mathrm{A} \neq}$ & $31 \pm 1^{\mathrm{a}, \mathrm{A}}$ & $58 \pm 3^{\mathrm{a}, \mathrm{A} \neq}$ \\
\hline & ${ }^{* * *} F=3860$ & ${ }^{* * *} F=5269$ & ${ }^{* * *} F=680$ & $* * * F=431$ & $* * * F=353$ & $* * * F=295$ \\
\hline PYInc & $101.65 \pm 0.05^{\mathrm{g}, \mathrm{C}}$ & $101.25 \pm 0.05^{\mathrm{i}, \mathrm{C} \neq}$ & $107.6 \pm 0.2^{\mathrm{i}, \mathrm{C}}$ & $106 \pm 3^{g, C}$ & $105.3 \pm 0.7^{g, D}$ & $105 \pm 1^{\mathrm{f}, \mathrm{D}}$ \\
\hline PYInc + 1C2 & $18 \pm 3^{\mathrm{b}, \mathrm{AB}}$ & $18.5 \pm 0.5^{\mathrm{ab}, \mathrm{A}}$ & $25 \pm 3^{\mathrm{b}, \mathrm{A}}$ & $46 \pm 7^{\mathrm{bc}, \mathrm{AB} \neq}$ & $30 \pm 2^{\mathrm{a}, \mathrm{A}}$ & $69 \pm 1^{\text {cde }, \mathrm{B} \neq}$ \\
\hline PYInc + 1ZP4 & $19 \pm 5^{\mathrm{b}, \mathrm{B}}$ & $37 \pm 3^{c, B} \neq$ & $37 \pm 5^{\mathrm{c}, \mathrm{B}}$ & $37 \pm 3^{\mathrm{ab}, \mathrm{A}}$ & $54.6 \pm 0.8^{\mathrm{d}, \mathrm{C}}$ & $72.2 \pm 0.7^{\mathrm{e}, \mathrm{C} \neq}$ \\
\hline \multirow[t]{3}{*}{ PYInc + EC30 } & $11 \pm 3^{\mathrm{a}, \mathrm{A}}$ & $16.4 \pm 0.5^{\mathrm{a}, \mathrm{A} \neq}$ & $22 \pm 2^{\mathrm{ab}, \mathrm{A}}$ & $52 \pm 7^{\mathrm{cd}, \mathrm{B}} \neq$ & $41 \pm 2^{\mathrm{b}, \mathrm{B}}$ & $61.6 \pm 0.6^{\mathrm{ab}, \mathrm{A} \neq}$ \\
\hline & ${ }^{* * *} F=528$ & ${ }^{* * * *} F=2052$ & ${ }^{* * * *} F=476$ & $* * * F=96.3$ & $* * * F=1607$ & $* * * F=1112$ \\
\hline & $* * *(F=404)$ & $* * *(F=172)$ & $* * *(F=387)$ & $* * *(F=108)$ & $* * *(F=84)$ & $*(F=2.52)$ \\
\hline
\end{tabular}

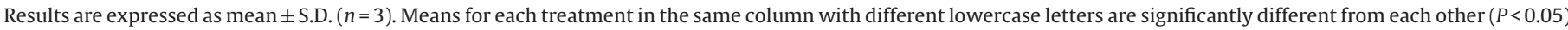

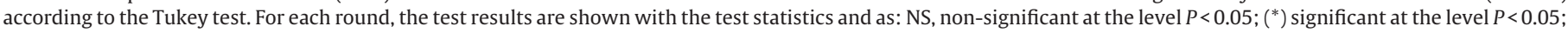

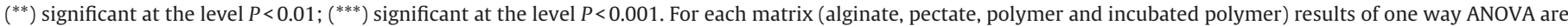

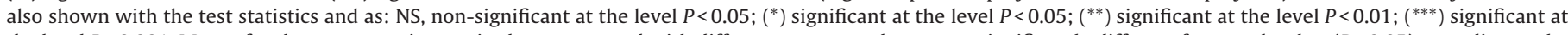

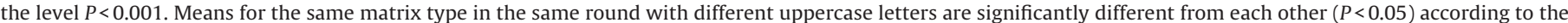

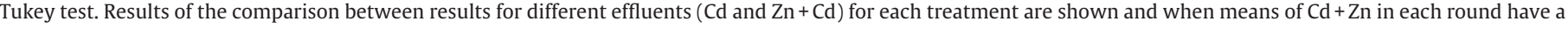
$\neq$ signal they are significantly different from means of outlet $C d(P<0.05)$ according to the $t$-test. 
Table 4

Adsorption of metal per unit weight of cells for each treatment ( $\mathrm{mg} \mathrm{Zn}^{-1}$ cell).

\begin{tabular}{|c|c|c|c|c|}
\hline \multirow[t]{2}{*}{ Treatment } & \multicolumn{2}{|l|}{$\mathrm{Zn}$} & \multicolumn{2}{|l|}{$\mathrm{Cd}$} \\
\hline & $100 \mathrm{mg} \mathrm{Zn/L}$ & $100 \mathrm{mg} \mathrm{Zn}+100 \mathrm{mg} \mathrm{Cd} / \mathrm{L}$ & $100 \mathrm{mg} \mathrm{Cd} / \mathrm{L}$ & $100 \mathrm{mg} Z \mathrm{n}+100 \mathrm{mg} C \mathrm{Cd} / \mathrm{L}$ \\
\hline$A+1 C 2$ & $0.9 \pm 0.1$ & $1.0 \pm 0.3$ & $2.15 \pm 0.09$ & $2.2 \pm 0.2$ \\
\hline$A+1 Z P 4$ & $1.3 \pm 0.7$ & $1.2 \pm 0.3$ & $1.6 \pm 0.1$ & $1.89 \pm 0.09$ \\
\hline$A+E C 30$ & $1.2 \pm 0.1$ & $1.1 \pm 0.1$ & $2.1 \pm 0.1$ & $1.49 \pm 0.06$ \\
\hline$P+1 C 2$ & $1.4 \pm 0.2$ & $1.3 \pm 0.2$ & $2.3 \pm 0.2$ & $2.2 \pm 0.2$ \\
\hline$P+1 Z P 4$ & $1.7 \pm 0.8$ & $1.7 \pm 0.7$ & $1.7 \pm 0.2$ & $1.8 \pm 0.2$ \\
\hline$P+E C 30$ & $0.82 \pm 0.08$ & $0.9 \pm 0.1$ & $1.4 \pm 0.1$ & $1.5 \pm 0.1$ \\
\hline$P Y+1 C 2$ & $1.9 \pm 0.8$ & $1.8 \pm 0.7$ & $2.2 \pm 0.4$ & $1.4 \pm 0.4$ \\
\hline$P Y+1 Z P 4$ & $1.0 \pm 0.8$ & $1.2 \pm 1.0$ & $2.5 \pm 0.6$ & $1.9 \pm 0.4$ \\
\hline$P Y+E C 30$ & $1.8 \pm 0.6$ & $1.4 \pm 0.6$ & $2.8 \pm 0.4$ & $2.0 \pm 0.5$ \\
\hline PYInc + 1C2 & $2.0 \pm 0.3$ & $1.8 \pm 0.7$ & $2.5 \pm 0.2$ & $1.9 \pm 0.7$ \\
\hline PYInc + 1ZP4 & $1.5 \pm 0.6$ & $1.5 \pm 0.6$ & $2.1 \pm 0.5$ & $1.7 \pm 0.6$ \\
\hline PYInc + EC30 & $2.2 \pm 0.2$ & $1.7 \pm 0.8$ & $2.5 \pm 0.5$ & $1.9 \pm 0.7$ \\
\hline
\end{tabular}

Results are expressed as mean \pm S.D. $(n=3)$. Averages presented considered removal efficiencies observed for the three rounds.
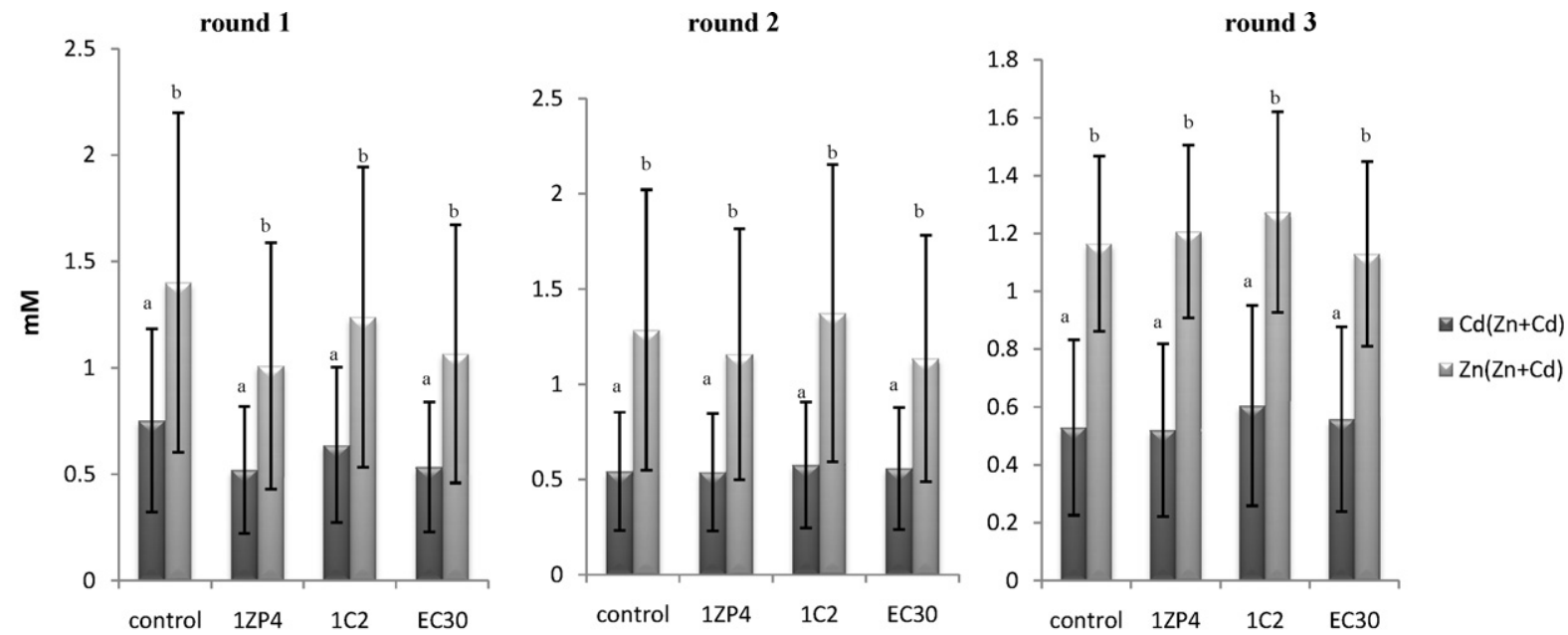

Results are expressed as mean \pm S.D. $(n=3)$. Means for the same bacterial treatment in each round with different letters are significantly different from each other $(P<0.05)$ according to the t-test.

Fig. 2. $\mathrm{Zn}$ and $\mathrm{Cd}$ levels in the combined outlet $(\mathrm{Zn}+\mathrm{Cd})$ in the alginate matrix with different bacteria applications (mM).
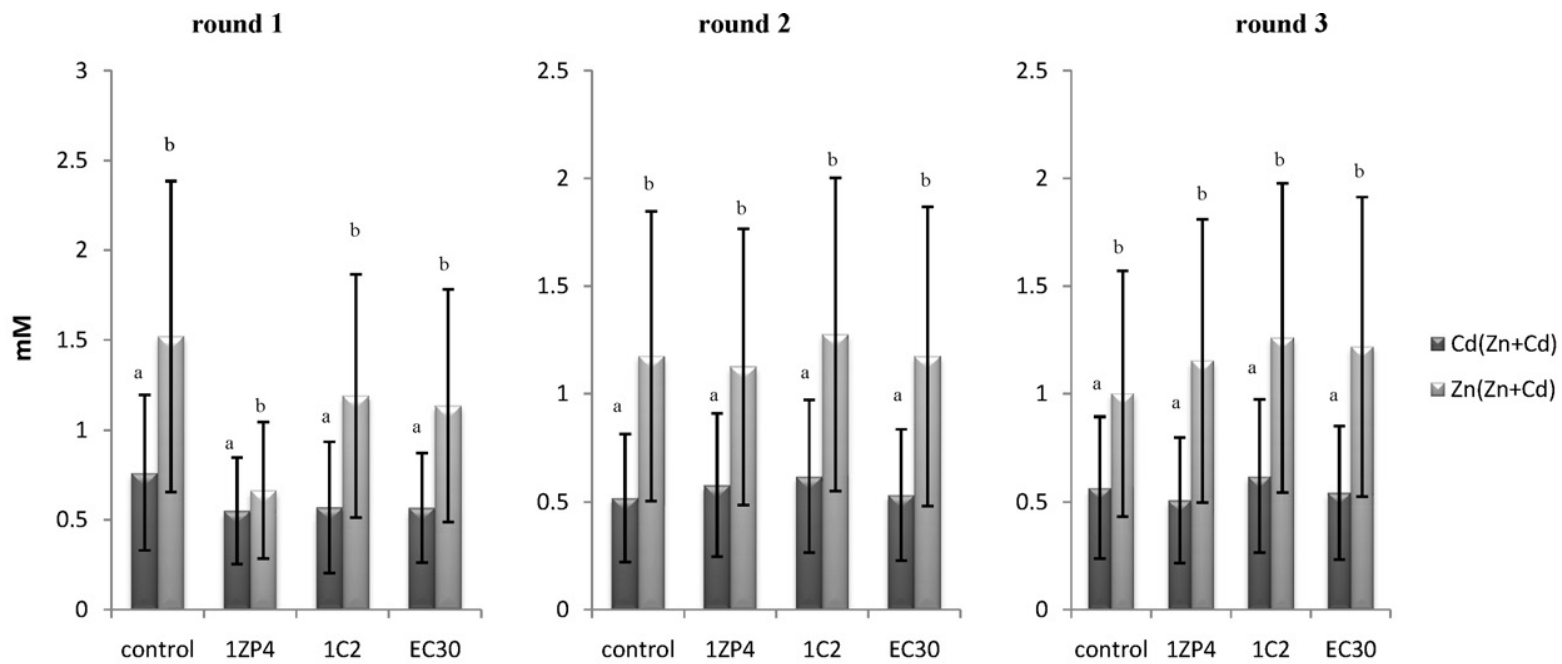

Results are expressed as mean \pm S.D. $(n=3)$. Means for the same bacterial treatment in each round with different letters are significantly different from each other $(P<0.05)$ according to the t-test.

Fig. 3. $\mathrm{Zn}$ and $\mathrm{Cd}$ levels in the combined outlet $(\mathrm{Zn}+\mathrm{Cd})$ in the pectate matrix with different bacteria applications (mM). 

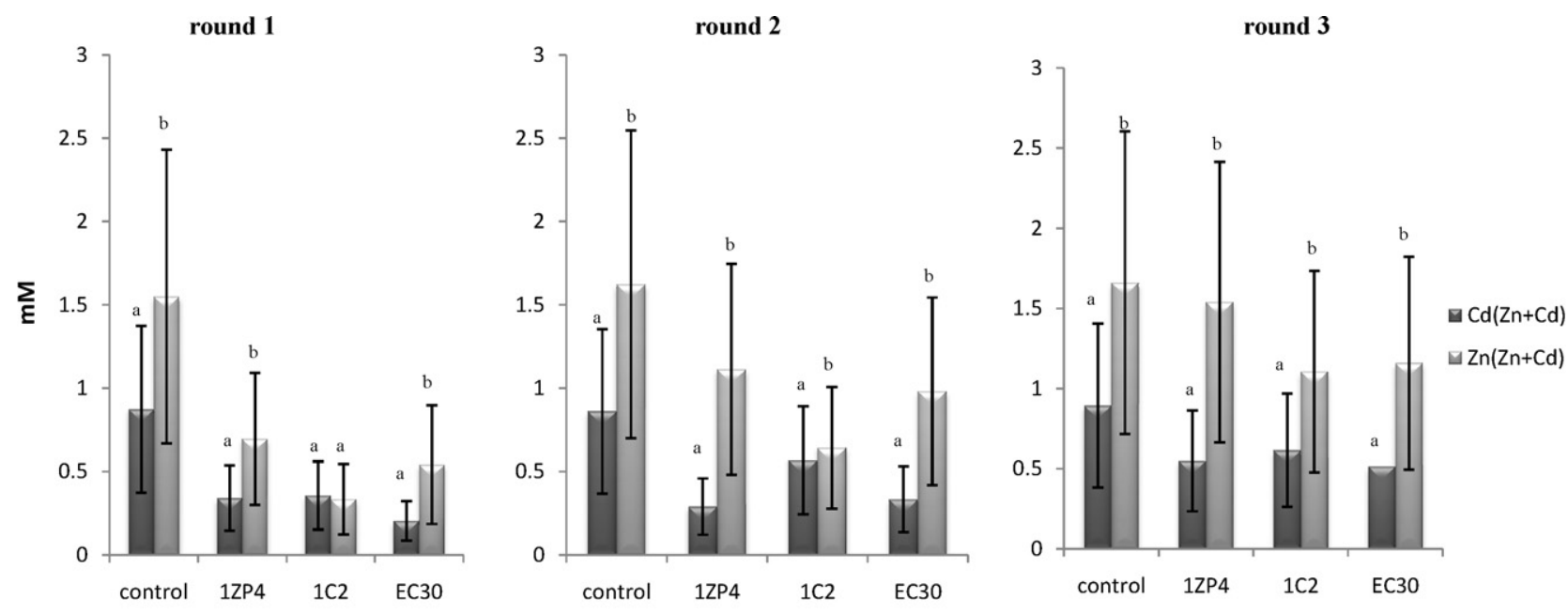

Results are expressed as mean \pm S.D. $(n=3)$. Means for the same bacterial treatment in each round with different letters are significantly different from each other $(P<0.05)$ according to the t-test.

Fig. 4. $\mathrm{Zn}$ and $\mathrm{Cd}$ levels in the combined outlet $(\mathrm{Zn}+\mathrm{Cd})$ in the synthetic polymer matrix with different bacteria applications ( $\mathrm{mM}$ ).

[32]). In the case of alginate - a linear polysaccharide that can be found in many algal species [33] and which has been extensively used in metal removal studies [34] - and pectate - a pectin compound which has been used to remove $\mathrm{Zn}$ in aqueous solutions by Khotimchenko et al. [13] - it appears that the process of ion-exchange takes place when metal binds to this matrix $[35,36]$.

Despite this adsorption capacity of the polymers, the present study showed that the immobilisation of bacteria increased the removal abilities of all the matrices (alginate, pectate and the synthetic polymer). In fact, bacteria have been successfully used as biosorbents [7-9] because of their small size, their ubiquity, ability to grow under controlled conditions and resilience to a wide range of contaminants [37]. Bacteria are known to produce extracellular polymeric substances which are composed by proteins, polysaccharides and uronic acid. These substances contain several functional groups like carboxyl, phosphoric, amine and hydroxyl groups $[38,39]$. Both the phosphoryl and carboxyl groups of the peptide chains in bacterial cell walls provide negatively charged sites in Gram-positive bacteria. For Gram-negative bacteria, such as 1ZP4, EC30 and 1C2, the phosphate groups within the lipopolysaccharides of their outer membrane are the primary sites for metal interaction, with only one of the carboxyl group in this net being free to interact with metals [37]. The process of binding of metal ions to bacteria involves electrostatic interaction between metal ions and the biomass [4] as bacteria have a net negative charge that favour the biosorption of metal [40], as observed in the present work. Further studies have shown a similar pattern when comparing the use of polymers alone and when immobilising microorganisms: For example, Sag et al. [41] have shown that when aqueous solutions of $\mathrm{Cu}$ were treated with $\mathrm{Ca}$-alginate immobilised Zooglea ramigera, an increase in $\mathrm{Cu}$ removal occurred from $64 \%$, for the treatment with only Ca-alginate, to $94 \%$. Aksu et al. [11] have also shown that after long periods, the adsorption capacity of alginate immobilised Chlorella vulgaris exceeded that of alginate alone. Synthetic responsive polymers have also been used successfully to control the attachment of bacterial cells to surfaces
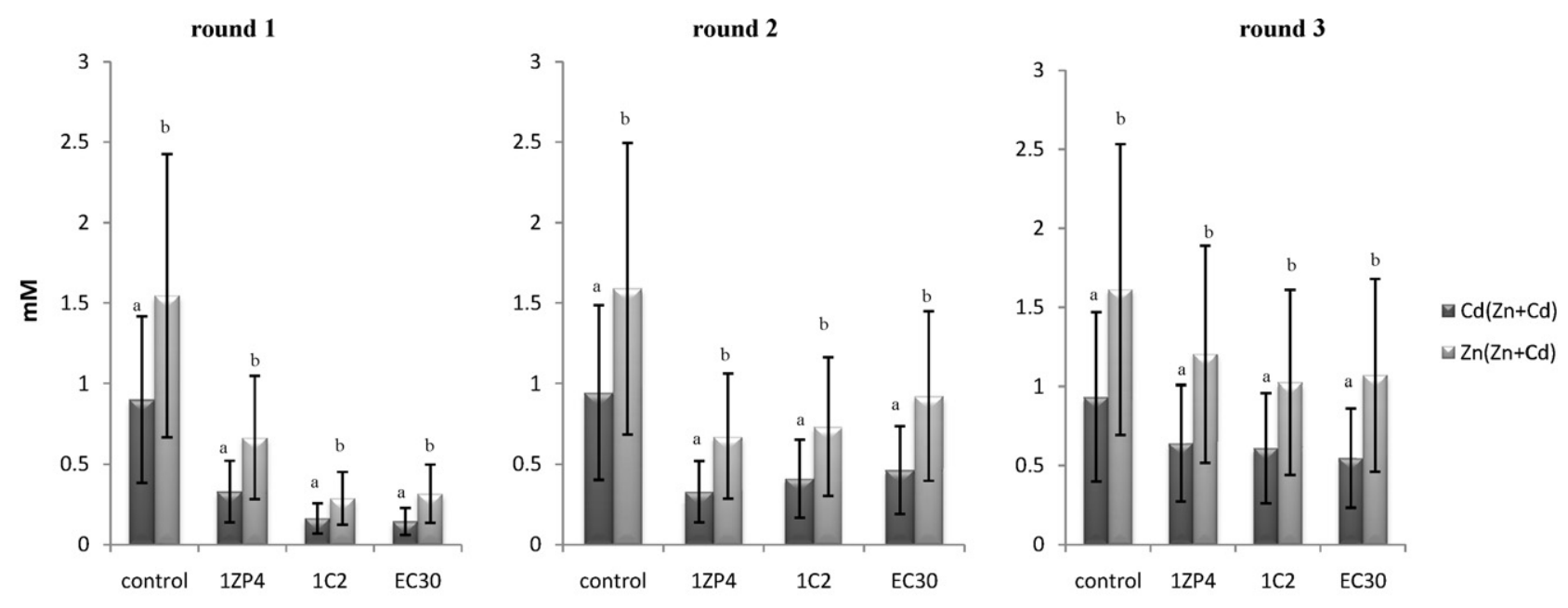

Results are expressed as mean \pm S.D. $(n=3)$. Means for the same bacterial treatment in each round with different letters are significantly different from each other $(P<0.05)$ according to the t-test.

Fig. 5. $\mathrm{Zn}$ and $\mathrm{Cd}$ levels in the combined outlet $(\mathrm{Zn}+\mathrm{Cd})$ in the incubated synthetic polymer matrix with different bacteria applications (mM). 
[42] demonstrating the attachment of Hallomonas and Staphylococcus strains to surface-grafted synthetic polymers. However, the amount of biosorbent, initial concentration of metal, presence of further contaminants in the aqueous solutions, structural properties of both the support matrix and the biosorbent material all affect the biosorption rate [34], rendering it difficult to compare results from different reports, and thus the main focus of this report is not to attempt such comparisons. The 3 selected strains - 1C2, 1ZP4 and EC30 - exhibited high resistance to $\mathrm{Cd}$ and $\mathrm{Zn}$ and all showed high specific growth rates when these heavy metals were present at different concentrations. Strains 1C2, 1ZP4 and EC30 are all Gram-negative and affiliated to genera Cupriavidus, Sphingobacterium and Alcaligenes, respectively. Many reports have shown that Gram-negative are more tolerant to heavy metals than Grampositive bacteria. This metal tolerance can be attributed to the interactions between microbial cell wall components and heavy metal ions both contributing to metal detoxification [43-45]. In the biosorption of complex solutions, different metal ions may compete for the active sites existing on the support matrix and/or on the cell wall of the biomass. Consequently, the preference of the biomass for some metals is an important issue [46], and thus the knowledge of the growth and metal resistance patterns of the bacterial species is of great importance.

Measurement of the growth of the selected strains in the presence of $\mathrm{Cd}$ and $\mathrm{Zn}$ indicated differences in toxicity towards the bacteria among the heavy metals. Specifically, the presence of $\mathrm{Cd}^{2+}$ inhibited the growth of the strains tested, except for strain EC30 that showed a remarkable capacity to tolerate $\mathrm{Cd}$ in solution, with only a $15-20 \%$ biomass reduction. $\mathrm{Zn}^{2+}$ caused also a reduction in biomass production; however in a less significant degree when compared to Cd. Strain EC30 apparently was more sensitive to $\mathrm{Zn}^{2+}$ than to $\mathrm{Cd}^{2+}$. When metal mixtures were present, the growth rate was lower than that observed when only $\mathrm{Zn}$ was tested. The decrease in biomass observed whenever metals were present possibly results from a decrease in the substrate utilization efficiency due to a higher energy cost of microorganisms subject to metal stress [47].

In the present study $1 \mathrm{C} 2$, a species affiliated to the Cupriavidus genera, was generally the one that most increased the removal performance of $\mathrm{Zn}$ (in single and binary solutions), especially when associated with the synthetic polymer. In contrast, EC30, a bacterium affiliated to the Alcaligenes genera, gave the most promising results for Cd removal in single and binary mixtures, especially when combined with the synthetic polymer. In fact, EC30 has also shown to be the most resistant to $\mathrm{Cd}$ in the tolerance study performed which may explain these results. Mondal et al. [48] reported the use a species of Ralstonia, phylogenetically related to Cupriavidus, Ralstonia eutropha, for the elimination of $\mathrm{Fe}, \mathrm{Mn}, \mathrm{Cu}, \mathrm{As}$ and $\mathrm{Zn}$, with removals of up to $65.2 \%, 72.7 \%, 98.6 \%, 8 \%$ and $99.3 \%$, respectively, from metal contaminated water. Species from the genera Alcaligenes (such as EC30) have also been reported by Chang and Tseng [49] as important in immobilised biomass strategies, and Diels et al. [50] have studied the application for heavy metal removal of composite membrane reactor immobilised Alcaligenes eutrophus bacteria with a reduction of metals such as $\mathrm{Cd}, \mathrm{Zn}, \mathrm{Cu}$, and $\mathrm{Pb}$ in solution from $100 \mathrm{ppm}$ to less than $50 \mathrm{ppb}$. As for strain 1ZP4, belonging to genera Sphingobacterium, there is also a study from Bootham et al. [51] describing Sphingobacterium mizutatae as being part of a bacterial consortium used to treat metal contaminated effluents.

The removal efficiencies registered in the present report, for a contact time of $2 \mathrm{~min}$, reach levels of $2.8 \mathrm{mg} \mathrm{Cd} \mathrm{g}^{-1}$ cell and $2.2 \mathrm{mg} \mathrm{Zn} \mathrm{g}^{-1}$ cell; a longer residence time could have allowed for higher uptakes. Arica et al. [34] used Ca alginate as a support for $\mathrm{Zn}$ biosorption with immobilised live and inactivated fungus Phanerochaete chrysosporium, and for a similar initial $\mathrm{Zn}$ concentration
(100 $\left.\mathrm{mg} \mathrm{L}^{-1}\right)$ removals of ca. $20-35 \mathrm{mg} \mathrm{Zng}^{-1}$ adsorbent were observed. In fact, these values are quite higher than those shown in this work, however the residence time was of $90 \mathrm{~min}$ while in the present study the average contact time was of 2 min. Also, and for solution of similar Cd initial concentration, Quintelas et al. [2] presented uptake levels of app. $10 \mathrm{mg} \mathrm{Cd} \mathrm{g}^{-1}$ Escherichia coli supported on kaolin, this time for a residence time of 10 days. Nevertheless, the levels of adsorption of the tested systems will depend not only on the characteristics of the used immobilisation media, but also on the residence time of the metals in the cartridge. Sag et al. [41] analysed the effect of flow rate in the adsorption of $\mathrm{Cu}$ to alginate and immobilised $Z$. ramigera and have showed that an increase in the flow of five times could result in decreases in the metal removal of up to 15 times.

\subsection{Removal of binary mixtures of metals by immobilised bacterial matrices}

Mixtures of Cd and Zn are typically found in contaminated effluents of industrial processes [52]; additionally, from a biological point of view Cd can be transported by the same transporters as $\mathrm{Zn}$ [53].Nevertheless, Fan et al. [54] have shown that when using binary mixtures of $\mathrm{Cd}$ and $\mathrm{Zn}$, the biosorption capacity of either metal was lower than that found in non-competitive conditions. However, this did not always occur in the present study. In some cases there was a differential increase in the removal abilities of either of the tested metals when present as a binary solution when compared to single solution. Such phenomenon may be explained by the hypothesis that the sorption of the other metallic contaminants in solution altered the conformation of the metal binding sites and increased the affinity of sites for that particular metal adsorption in that specific combination of matrix, bacteria and usage [10]. On the other hand, the opposite effect was observed in some cases where there was a decrease in Cd or Zn removal capacities of specific matrix-bacteria combinations. The most likely reason for this antagonistic effect may be the competition for adsorption sites on the cell and polymer surfaces. Chen et al. [10] also found that $\mathrm{Cd}$ uptake capacity was slightly reduced when $\mathrm{Pb}$ and $\mathrm{Hg}$ are present in solution, suggesting that in Ca-alginate immobilised Microcystis aeruginosa most Cd adsorption sites were specific, whereas some of these Cd binding sites were also capable of binding other metals. Despite these variations in the removal of metals in the binary mixture levels of $\mathrm{Cd}$ at the outlet were lower than those of $\mathrm{Zn}$, and in the large majority of cases this trend was significant. The preference of a sorbent for a metal may be explained on the basis of electronegativity of the metal ions $(\mathrm{Cd}=1.69$ and $\mathrm{Zn}=1.65$, according to the Pauling scale), molecular weight $(\mathrm{Cd}=112.4$ and $\mathrm{Zn}=65.4)$ and ionic radius $(\mathrm{Cd}=95$ and $\mathrm{Zn}=74)$, with the first being positively related to the adsorption capacity, and the second and third being inversely related to it [2]. In the present study, electronegativity seems to play an important role in the affinity of the tested combinations to $\mathrm{Cd}$, but other conditions such as ionization energy can have contributed to influence the adsorption behaviour of the metals [55].

\section{Conclusions}

Immobilisation of bacteria in naturally occurring and synthetic polymers increased the removal abilities of all the matrixes (alginate, pectate and synthetic cross-linked polymer), with up to 12 -fold when compared to the use of the polymers alone. Strain $1 \mathrm{C} 2$, a species from the Cupriavidus genera, generally has the best capacity for increasing the removal of $\mathrm{Zn}$ when immobilised on any of the polymers, in single and binary solutions, especially when associated with the synthetic polymer. EC30, a bacteria affiliated to the Alcaligenes genera, was the most promising concerning 
Cd removal in single and binary mixtures, again when combined with the synthetic polymer. Thus, the combinations that would be recommended to clean-up aqueous solutions containing $\mathrm{Zn}$ or Cd would be respectively $1 \mathrm{C} 2$ or EC30 immobilised on the synthetic polymer (PY +1C2 and PY +EC30). Synthetic cross-linked polymers are promising matrixes and should be explored further in immobilised microbial cartridges. In this format, in addition to the promising results presented here, synthetic polymers have the added advantage of being easily reusable, unlike their natural counterparts.

\section{Acknowledgments}

The authors wish to thank Câmara Municipal de Estarreja for the provision of access to the sampling site. Ana Marques and Carlos Pires had financial support from Fundação para a Ciência e a Tecnologia, grants SFRH/BPD/34585/2007 and SFRH/BD/25493/2005, respectively.

\section{References}

[1] J. Wang, C. Chen, Biosorbents for heavy metals removal and their future, Biotechnol. Adv. 27 (2009) 195-226.

[2] C. Quintelas, Z. Rocha, B. Silva, B. Fonseca, H. Figueiredo, T. Tavares, Removal of $\mathrm{Cd}(\mathrm{II}, \mathrm{Cr}(\mathrm{VI}), \mathrm{Fe}(\mathrm{III})$ and $\mathrm{Ni}(\mathrm{II})$ from aqueous solutions by an $E$. coli biofim supported on kaolin, Chem. Eng. J. 149 (2009) 319-324.

[3] B. Volesky, Detoxification of metal bearing effluents: biosorption for the next century, Hydrometallurgy 59 (2001) 203-216.

[4] K.K. Krishnani, X. Mengb, C. Christodoulatos, V.M. Bodduc, Biosorption mechanism of nine different heavy metals onto biomatrix from rice husk, J. Hazard. Mater. 153 (2008) 1222-1234

[5] E.I. Unuabonah, K.O. Adebowale, B.I. Olu-Owolabi, Kinetic and thermodynamic studies of the adsorption of lead (II) ions onto phosphate modified kaolinite clay, J. Hazard. Mater. 144 (2007) 386-395.

[6] A.I. Zouboulis, M.X. Loukidou, K.A. Matis, Biosorption of toxic metals from aqueous solutions by bacteria strains isolated from metal polluted soils, Process Biochem. 39 (2004) 909-916.

[7] A. Nakajima, T. Tsaruta, Competitive biosorption of thorium and uranium by Micrococcus luteus, J. Radioanal. Nucl. Chem. 260 (2004) 13-18.

[8] A. Selatnia, M.Z. Bakhti, A. Madani, I. Kertous, Y. Mansouri, Biosorption of $\mathrm{Cd}^{2+}$ from aqueous solution by a $\mathrm{NaOH}$ treated bacterial dead Streptomyces rimosus biomass, Hydrometallurgy 75 (2004) 11-24.

[9] M. Ziagova, G. Dimitriadis, D. Aslanidou, X. Papaioannou, E.I. Tzannetaki, M. Liakopoulou-Kyriakides, Comparative study of $\mathrm{Cd}(\mathrm{II})$ and $\mathrm{Cr}(\mathrm{VI})$ biosorption on Staphylococcus xylosus and Pseudomonas sp. in single and bynary mixtures, Biores. Technol. 98 (2007) 2859-2865.

[10] J.Z. Chen, X.C. Tao, T. Zhang, Z.L. Liu, Biosorption of lead, cadmium and mercury by immobilised Microcystis aeruginosa in a column, Process Biochem. 40 (2005) 3675-3679.

[11] Z. Aksu, G. Egretli, T. Kutsal, A comparative study of copper (II) biosorption on Ca-alginate, agarose and immobilised C. vulgaris in a packed bed colum, Process Biochem. 33 (1998) 393-400.

[12] K Akhtar, M.W. Akhtar, A.M. Khalid, Removal and recovery of uranium from aqueous solutions by Trichoderma harzianum, Water Res. 41 (2007) 1366-1378.

[13] M.Y. Khotimchenko, E.A. Kolenchemko, Y.S. Khotimchenko, Zinc binding activity of different pectin compounds in aqueous solutions, J. Colloid Interface Sci. 323 (2008) 216-222.

[14] C. de las Heras Alarcón, B. Twaites, D. Cunliffe, J.R. Smith, C. Alexander, Grafted thermo- and $\mathrm{pH}$ responsive co-polymers: Surface-properties and bacterial adsorption, Int. J. Pharmaceut. 295 (2005) 77-91.

[15] C.F. Degiorgi, R.A. Pizarro, E.E. Smolko, S. Lora, M. Carenza, Hydrogels for immobilisation of bacteria used in the treatment of metal contaminated wastes, Radiat.Phys. Chem. 63 (2002) 109-113.

[16] S. Mor, K. Ravindra, N.R. Bishnoi, Adsorption of chromium from aqueous solution by activated alumina and activated charcoal, Biores. Technol. 98 (2007) 954-957.

[17] V.P.J. Vilar, R.J.E. Martins, C.M.S. Botelho, R.A.R. Boaventura, Removal of Cu and $\mathrm{Cr}$ from an industrial effluent using a packed bed column with algae Gelidiumderived material, Hydrometallurgy 96 (2009) 42-46.

[18] A.P.G.C. Marques, A.O.S.S. Rangel, P.M.L. Castro, Zn accumulation in plant species indigenous to a Portuguese polluted site: relation with soil contamination, J. Environ. Qual. 36 (2007) 646-653.

[19] I. Tiago, I. Teixeira, S. Silva, P. Chung, A. Veríssimo, C. Manaia, Metabolic and genetic diversity of mesophilic and thermophilic bacteria isolated from composted municipal sludge on poly-epsilon-caprolactones, Curr. Microbiol. 49 (2004) 407-414.

[20] S.K. Alexander, D. Strete, Microbiology: a Photographic Atlas for the Laboratory, 2nd ed., Benjamin-Cummings Publishing Company, San Francisco, 2001.

[21] R.G.E. Murray, R.N. Doetsch, F. Robinow, Determinative and cytological light microscopy, in: P. Gerhardt, R.G.E. Murray, W.A. Wood, N.R. Krieg (Eds.), Meth- ods for General and Molecular Bacteriology, American Society for Microbiology, Washington, DC, 1994, pp. 21-41.

[22] R.M. Smibert, N.R. Krieg, Phenotypic characterization, in: P. Gerhardt, R.G.E. Murray, W.A. Wood, N.R. Krieg (Eds.), Methods for General and Molecular Bacteriology, American Society for Microbiology, Washington, DC, 1994, pp. 611-651.

[23] G. Gomori, Preparation of buffers, Methods Enzymol. 1 (1990) 138-146.

[24] F.A. Rainey, N. Ward-Rainey, R.M. Kroppenstedt, E. Stackebrandt, The genus Nocardiopsis represents a phylogenetically coherent taxon and a distinct actinomycete lineage: proposal of Nocardiopsaceae fam. Nov, Int. J. Syst. Bacteriol. 46 (1996) 1088-1092.

[25] D.J. Lane, 16S/23S sequencing, in: E. Stackebrandt, M. Goodfellow (Eds.), Nucleic Acid Techniques in Bacterial Systematics, Wiley, Chichester, 1991, pp. 171-204.

[26] T.A. Hall, BioEdit: a user-friendly biological sequence alignment editor and analysis program for Windows 95/98/NT, Nucleic Acids Symp. Ser. 41 (1999) 95-98.

[27] D.A. Benson, I. Karsch-Mizrachi, D.J. Lipman, J. Ostell, D.L. Wheeler, GenBank, Nucleic Acids Res. 35 (2007) 21-25.

[28] N.W. Turner, A.P.F. Turner, S.A. Piletsky, Controlled release of the herbicide simazine from computationally designed molecularly imprinted polymers, J. Controlled Rel. 108 (2005) 132-139.

[29] S. Barral, A. Guerreiro, M. Villa-García, M. Rendueles, M. Díaz, S. Piletsky, Synthesis of 2-(diethylamino) ethyl methacrylate-based polymers: Effect of crosslinking degree, porogen and solvent on the textural properties and protein adsorption performance, React. Funct. Polym. 70 (2010) 890-899.

[30] S.E.M Escamilla, L. Dendooven, I.P. Magaña, S.R. Parra, M.M. De la Torre, Optimization of gibberellic acid production by immobilised Gibberella fujikuroi mycelium in fluidized bioreactors, J. Biotechnol. 76 (2000) $147-155$.

[31] M.C. Montes, I.P. Magana, Delta'-dehydrogenation of steroids by Arthrobacter simplex immobilised in calcium polygalacturonate beads, J. Ind. Microbiol. 8 (1991) 259-264.

[32] V. Utgikar, B.Y. Chen, H.H. Tabak, D.F. Bishop, R. Govnd, Treatent of acid mine drainage. Equilibrium biosorption of zinc and copper on non viable activated sludge, Int. Biodeter. Biodegrad. 46 (2000) 19-28.

[33] B. Stokke, O. Smidsrod, P. Bruheim, G. Skjak-Braek, Distribution of urinate residues in alginate chains in relation to alginate gelling properties, Macromolecules 24 (1991) 4637-4645.

[34] M.Y. Arica, C. Arpa, A. Ergene, G. Bayramoglu, O. Genç, Ca-alginate as a support for $\mathrm{Pb}(\mathrm{II})$ and $\mathrm{Zn}(\mathrm{II})$ biosorption with immobilised Phanerochaete chrysosporum, Carbohydr. Polym. 52 (2003) 167-174.

[35] S. Myklestad, Ion exchange properties of brown algae. Determination of rate mechanism for calcium hydrogen ion exchange for particles from Laminaria hyperborean and Laminaria digitata, J. Appl. Chem. 18 (1968) 30-36.

[36] A.J. Paskins-Hurlburt, Y. Tanaka, S.C. Skoryna, W. Moore, J.F. Stara, The binding of lead by pectic polyelectrolyte, Environ. Res. 14 (1977) $128-140$.

[37] M.M. Urrutia, General bacterial sorption processes, in: J. Wase, C. Forster (Eds.), Biosorbents for Metal Ions, CRC Press, London, UK, 1997, pp. 39-66.

[38] E.D. Van Hullebush, M.H. Zandvoort, P.N.L. Lens, Metal immobilisation by biofilms: mechanisms and analytical tools, Rev. Environ. Sci. Biol. Technol. 2 (2003) 9-33.

[39] A. Omoike, J. Chorover, Spectroscopic study of extracellular polymeric substances from Bacillus subtilis: aqueous chemistry and adsorption effects, Biomacromolecules 5 (2004) 1219-1230.

[40] B. Silva, H. Figueiredo, C. Quintelas, T. Tavares, I.C. Neves, Zeolites as supports for the biorecovery of hexavalent and trivalent chromium, Microporous Mesoporous Mater. 116 (2008) 555-560.

[41] Y. Sag, Z. Nourbakhsh, Z. Aksu, T. Kutsal, Comparison of Ca-alginate and immobilised Z. ramigera as sorbents for copper removal, Process Biochem. 30 (1995) $175-181$.

[42] L.K. Ista, V.H. Perez-Luna, G.P. Lopez, Surface-grafted, environmentally sensitive polymers for biofilm release, Appl. Environ. Microbiol. 65 (1999) 1603-1609.

[43] Å. Frostegård, A. Tunlid, E. Bååth, Phospholipid fatty acid composition, biomass, and activity of microbial communities from two soil types experimentally exposed to different heavy metals, Appl. Environ. Microbiol. 59 (1993) 3605-3617.

[44] T.M. Roane, S.T. Kellog, Characterisation of bacterial communities in heavy metal contaminates soils, Can. J. Microbiol. 42 (1996) 593-603.

[45] T. Pennanen, A. Frostegård, H. Fritz, Phospholipid fatty acid composition and heavy metal tolerance of soil microbial communities along two heavy metalpolluted gradients in coniferous forest, Appl. Environ. Microbiol. 62 (1996) $420-428$.

[46] E. Romera, F. Gonzalez, A. Ballester, M.L. Blazquez, J.A. Munoz, Biosorption of heavy metals by Fucus spiralis, Biores. Technol. 99 (2008) 4684-4693.

[47] K.E. Giller, E. Witter, S.P. McGrath, Heavy metals and soil microbes, Soil Biol. Biochem. 41 (2009) 2031-2037.

[48] P. Mondal, C.B. Majumber, B. Mohanty, Treatment of arsenic contaminated water in a batch reactor by using Ralstonia eutropha MTCC 2487 and granular activated carbon, J. Hazard. Mater. 153 (2008) 588-599.

[49] C.C. Chang, S.K. Tseng, Immobilisation of Alcaligenes eutrophus using PVA crosslinked with sodium nitrate, Biotechnol. Tech. 12 (1998) 865-868. 
[50] L. Diels, S. van Roya, K. Somersa, I. Willemsa, W. Doyenb, M. Mergeaya, D. Springaela, R. Leysenb, The use of bacteria immobilised in tubular membrane reactors for heavy metal recovery and degradation of chlorinated aromatics, J. Membr. Sci. 100 (1995) 249-258.

[51] C. Boothman, S. Hockin, D.E. Holmes, G.M. Gadd, J.R. Lloyd, Molecular analysis of a sulphate-reducing consortium used to treat metal-containing effluents, BioMetals 19 (2006) 601-609.

[52] C. Baird, M. Cann, Environmental Chemistry, 3rd ed., W.H. Freeman and Company, New York, 2005.
[53] S. McEldowney, Microbial biosorption of radionuclides in liquid effluent treatment, Appl. Biochem. Biotechnol. 26 (1990) 159-180.

[54] T. Fan, Y. Liu, B. Feng, G. Zeng, C. Yang, M. Zhou, H. Zhou, Z. Tan, X. Wang Biosorption of cadmium (II), zinc (II) and lead (II9 by Penicillium simplicissimum: isotherms, kinetics and thermodynamics, J. Hazard. Mater. 160 (2008) 655-661.

[55] A.S. Ekop, N.O. Eddy, Adsorption of $\mathrm{Pb}^{2+}, \mathrm{Zn}^{2+}$ and $\mathrm{Ni}^{2+}$ from Aqueous Solution by Helix aspera shell, E-J. Chem. 6 (2009) 1029-1034. 